\title{
Assessment of Genetic Polymorphism in Sugarcane Somaclones by Using Random Amplified Polymorphic DNA
}

\author{
S. J. Mallikarjuna*, M. Hemanth Kumar, D. Mohan Reddy, \\ P. Sudhakar and T. Hemalatha \\ Department of Genetics and Plant Breeding, S.V. Agricultural College, Tirupati, India \\ *Corresponding author
}

\section{A B S T R A C T}

\section{Keywords}

RAPD, Somaclones, Polymorphism, EMS, Sodium nitrite

Article Info

Accepted:

15 May 2018

Available Online:

10 June 2018
DNA was extracted from plants and RAPD analysis was performed for fourteen treatments with two random oligonucleotide primers (OPA-01 and OPB-11). Among fourteen treatments, plants derived from the treatments $\mathrm{T}_{9}, \mathrm{~T}_{11}$, and $\mathrm{T}_{12}$ produced polymorphism $\mathrm{T}_{12}$ was found to exhibit maximum polymorphism at 1.0 $\mu \mathrm{M}$ EMS in 2009T5. The clone, 2009T5 produced more variation than 2008T42. Sodium nitrite did not produce any variation.

\section{Introduction}

Sugarcane is globally a major source of raw material for the production of commercial sugar and has multipurpose crop providing not only sugar, but also a series of value added products and by-products such as energy, chemicals, and single cell protein, ethanol, bio-gas, fertilizer, fibre board and paper, polishers, cosmetics and candles.

Although many countries are producers, only six of them account for $65 \%$ of the world's entire sugarcane production. Among these Brazil is the largest one (Viera 2002). It is very urgent to increase cane productivity without further area expansion to meet the future need of sugar and gur. The chemical composition of a matured, sound and normal sugarcane stalk of the species Saccharum officinarum are water $74.96 \%$, sugar $13.40 \%$, fibre $10.04 \%$, ash $0.64 \%$, N2 bodies $0.58 \%$, fat and wax $0.38 \%$. Sugarcane is propagated vegetatively for commercial planting by stem cuttings.

Tissue culture offers an opportunity to mass produce disease free planting material and is now used to supplement commercial sugarcane propagation in many countries including Brazil, the United States, India and Cuba (Lakshmanan et al., 2006). Somaclones may show variation for different parameters like yield, sugar recovery, disease resistance, 
drought and salt tolerance, maturity etc. It is not controversial that tissue culture tools are playing their part in sugarcane improvement and at the same time for a plant breeder assessment of genetic diversity.

Genetic markers have contributed much to understanding plant genetic diversity. Molecular markers are extensively being used to measure the variability present at genetic level, within and among the genotypes. The most commonly applied molecular markers used to study polymorphism are random amplified polymorphic DNA (RAPD).

Detection of somaclonal variants in early stages reduces the cost involved in field evaluation. Several molecular markers are increasingly being used to study the distribution and patterns of genetic diversity in populations at genetic level, within and among the genotypes.

The most commonly applied molecular markers used to study polymorphism are random amplified polymorphic DNA (RAPDs) and simple sequence repeat (SSRs) which were used to measure the variability present in the somaclones (Yadav et al., 2006; Lal et al., 2008; Shahid et al., 2012; Sobakumari, 2012). The main advantage of RAPDs is that they are quick and easy to assay requiring low quantities of template DNA. Moreover, RAPDs have a very high genomic abundance and are randomly distributed throughout the genome.

Hence, the present investigation was taken up to develop a protocol for production of somaclonal variation in young leaf roll explants and detection of polymorphism in somaclones by use of RAPDs in two high yielding and high sucrose sugarcane genotypes, 2008T42 (medium duration and susceptible to red rot) and 2009T5 (short duration and susceptible to smut).

\section{Materials and Methods Plant material}

The tissue culture seedlings used for studying polymorphism were generated from twelve treatments which include two clones (2008T42 and 2009T5) treated with two mutagenic chemicals (sodium nitrite and EMS). Each chemical had three levels (3mg, $5 \mathrm{mg}$ and $7 \mathrm{mg}$ of sodium nitrite and $0.6 \mu \mathrm{M}$, $0.8 \mu \mathrm{M}$ and $1.0 \mu \mathrm{M}$ of EMS) along with two treatments which served as control without mutagenic chemicals (Table 1).

In present study for RAPD analysis was performed for fourteen treatments. Ten random plants were taken from each treatment derived by callus culture using mutagenic chemicals in the sugarcane clones, 2008T42 and 2009T5 to assess polymorphism.

\section{Isolation of genomic DNA}

Total genomic DNA was isolated from fresh leaves by modified Gentra Kit method DNA sample were quantified by spectrophotometer (BIOMATE 3) and also in $8 \%$ agarose gels. The DNA was diluted in TE buffer to working concentration of $10 \mathrm{ng} / \mathrm{ul}$.

\section{Primer Selection and Survey}

Based on the previous investigations on RAPD analysis carried out with sugarcane embryogenic cultures and somaclones, 60 oligonucleotide primers of different sets (OPA, OPB, OPC and OPD) from Operon Technology Inc., USA were considered.

Among the primers screened for sugarcane genome, the best-suited 20 primers that showed distinct banding pattern were selected for the present RAPD study. A pilot project was run with 20 primers to detect somaclones in two random treatments. 


\section{PCR amplification and gel electrophoresis}

PCR reaction was carried out in $25 \mu 1$ reaction mixture containing $50 \mathrm{ng}$ of template (genomic DNA), $25 \mathrm{mM} \mathrm{MgCl} 2$ (Eppendorf, Hamburg, Germany), $10 \mathrm{mM}$ of each dNTPs (Eppendorf, Hamburg, Germany), 2U of Taq polymerase (Eppendorf, Hamburg, Germany) and $10 \mathrm{pM}$ of primer in a $1 \mathrm{xPCR}$ reaction buffer (Eppendorf, Hamburg, Germany). The amplification reaction was performed in the Eppendorf Master cycler with an initial denaturation for $2 \mathrm{~min}$ at $94^{\circ} \mathrm{C}$, then 32 cycles: 1 min denaturation at $94^{\circ} \mathrm{C} ; 1 \mathrm{~min}$ annealing at $37^{\circ} \mathrm{C} ; 2$ min extension at $72^{\circ} \mathrm{C}$. Final extension was carried out at $72^{\circ} \mathrm{C}$ for $7 \mathrm{~min}$. Amplified products were analyzed through electrophoresis on $1 \%$ agrose gel containing $0.5 \mathrm{X}$ TBE (Tris Borate EDTA) at 100 Volts for 2 hours, the gel contained $0.5 \mu \mathrm{g} / \mathrm{ml}$ ethidium bromide to stain the DNA and photograph was taken under UV light using gel documentation system (Alpha Innotech, USA).

\section{Data analysis}

The data generated from each primer - gel run was recorded in a matrix identifying the prescence (1) or absence (0) of each RAPD band of a particular molecular weight.

\section{Results and Discussion}

Out of 20 random oligonucleotide primers only two primers (OPA-1 and OPB-11) were found to be polymorphic and reproducible in initial expermentation. Hence detection of somaclones in all the 14 treatments was carried out using the two primers. The primers revealed a total of 159 clear and easily scorable bands. The polymorphic primers generated 77 DNA fragments for OPA-1 and 82 for OPB-11. Of the 159 bands, 6 were polymorphic, while 153 were monomorphic, depicting 3.92 percent polymorphism. The size of the bands that were produced in the PCR reactions ranged from 200-3000 bp, but most of the bands were between 300 and 3000 bp. The primers were able to amplify the genomic DNA giving both monomorphic and polymorphic bands.

Among all treatments, polymorphism was recorded only in $T_{9}, T_{11}$ and $T_{12}$ treatments. Maximum polymorphism (25 per cent) was recorded in the treatment, EMS $1.0 \mu \mathrm{M}$ in $2009 \mathrm{~T} 5\left(\mathrm{~T}_{12}\right)$ with OPA-1 primer and minimum (16.6 per cent) was recorded with OPB-11 primer (Plate.no. 12 and 13).

In the treatment of EMS $1.0 \mu \mathrm{M}$ in 2008T42 $\left(\mathrm{T}_{9}\right), \quad 16.6$ per cent polymorphism was recorded with both the primers (Plate.no.8 and 9). Similarly, in EMS $0.8 \mu \mathrm{M}$ in 2009T5 (T11) treatment, 11.1 per cent polymorphism was recorded with OPA-1 and 16.6 per cent with OPB-11 (Plate.no.10 and 11).

The results revealed that among fourteen treatments, plants derived from the treatments of $\mathrm{T}_{9}$ (EMS $1.0 \mu \mathrm{M}$ in 2008T42), $\mathrm{T}_{11}$ (EMS $0.8 \mu \mathrm{M}$ in 2009T5) and $\mathrm{T}_{12}$ (EMS $1.0 \mu \mathrm{M}$ in 2009T5) showed polymorphism. However, $T_{12}$ was found to be exhibited maximum polymorphism at $1.0 \mu \mathrm{M}$ EMS in 2009T5. The clone, 2009T5 produced more variation than $2008 \mathrm{~T} 42$.

From the results it can be concluded that higher concentrations of EMS $(0.8 \mu \mathrm{M}$ and 1.0 $\mu \mathrm{M})$ exhibited polymorphism in both sugarcane clones which indicated the production of somaclones. Whereas, in case of sodium nitrite treatments polymorphism was not recorded. It may require a higher concentration than the treatments studied to produce somaclones. EMS was found to be better than sodium nitrite in creating variation. EMS at $1.0 \mu \mathrm{M}$ concentration showed good response in callusing, shooting, rooting and also derived more variants. 
Table.1

\begin{tabular}{|c|c|c|c|}
\hline Treatments & Variety & $\begin{array}{c}\text { MS media + 4mg l } \mathrm{l}^{-1} 2,4-\mathrm{D}+ \\
\text { Sodium nitrite }\left(\mathrm{mg} \mathrm{l}^{-1}\right)\end{array}$ & $\begin{array}{c}\text { MS media + 4mg } \mathrm{I}^{-1} 2,4-\mathrm{D} \\
+\mathrm{EMS}(\mu \mathrm{M})\end{array}$ \\
\hline$T_{1}$ & 2008T42 & 3 & 0 \\
\hline$T_{2}$ & 2008T42 & 5 & 0 \\
\hline$T_{3}$ & 2008T42 & 7 & 0 \\
\hline$T_{4}$ & 2009T5 & 3 & 0 \\
\hline$T_{5}$ & 2009T5 & 5 & 0 \\
\hline$T_{6}$ & 2009T5 & 7 & 0 \\
\hline $\mathbf{T}_{7}$ & 2008T42 & 0 & 0.6 \\
\hline$T_{8}$ & 2008T42 & 0 & 0.8 \\
\hline$T_{9}$ & 2008T42 & 0 & 1.0 \\
\hline$T_{10}$ & 2009T5 & 0 & 0.6 \\
\hline$T_{11}$ & 2009T5 & 0 & 0.8 \\
\hline$T_{12}$ & 2009T5 & 0 & 1.0 \\
\hline$C_{1}$ & 2008T42 & 0 & 0 \\
\hline C2 & 2009T5 & 0 & 0 \\
\hline
\end{tabular}

Table.2 Sequence of the primers (RAPD)

\begin{tabular}{|c|l|l|}
\hline S. No & Primer & Sequence $\mathbf{( 5 - 3}$ ) \\
\hline $\mathbf{1}$ & OPA-01 & CAGGCCCTTC \\
\hline $\mathbf{2}$ & OPA-02 & TGCCGAGCTG \\
\hline $\mathbf{3}$ & OPA-03 & AGTCAGCCAC \\
\hline $\mathbf{4}$ & OPA-0 4 & AATCGGGCTG \\
\hline $\mathbf{5}$ & OPA-05 & AGGGGTCTTG \\
\hline $\mathbf{6}$ & OPA -06 & GGTCCCTGAC \\
\hline $\mathbf{7}$ & OPA -07 & GAAACGGGTG \\
\hline $\mathbf{8}$ & OPA-08 & GTGACGTAGG \\
\hline $\mathbf{9}$ & OPA-09 & GGGTAAGCCC \\
\hline $\mathbf{1 0}$ & OPA-10 & GTGATCGCAG \\
\hline $\mathbf{1 1}$ & OPA- 11 & CAATCGCCGT \\
\hline $\mathbf{1 2}$ & OPA-12 & TCGGCGATAG \\
\hline $\mathbf{1 3}$ & OPA -14 & TCTGTGCTGG \\
\hline $\mathbf{1 4}$ & OPA-20 & GTTGCGATCC \\
\hline $\mathbf{1 5}$ & OPB-01 & CTTTCGCTCC \\
\hline $\mathbf{1 6}$ & OPB-02 & TGATCCCTGG \\
\hline $\mathbf{1 7}$ & OPB-03 & CATCCCCCTG \\
\hline $\mathbf{1 8}$ & OPB-06 & TGCTCTGCCC \\
\hline $\mathbf{1 9}$ & OPB-10 & CTGCTGGGAC \\
\hline $\mathbf{2 0}$ & OPB -11 & CCTTGACGCA \\
\hline
\end{tabular}


Table.3 Polymorphism in somaclones as revealed by RAPD

\begin{tabular}{|c|c|c|c|c|c|c|}
\hline \multirow{3}{*}{$\begin{array}{l}\text { Treat- } \\
\text { ments }\end{array}$} & \multicolumn{6}{|c|}{ Primer } \\
\hline & \multicolumn{3}{|c|}{ OPA 1} & \multicolumn{3}{|c|}{ OPB11 } \\
\hline & Total bands & $\begin{array}{c}\text { Polymorphic } \\
\text { band }\end{array}$ & $\begin{array}{c}\text { \% Polymor- } \\
\text { phism }\end{array}$ & $\begin{array}{l}\text { Total } \\
\text { bands }\end{array}$ & $\begin{array}{l}\text { Polymorphic } \\
\text { bands }\end{array}$ & $\begin{array}{l}\text { \% Polymor- } \\
\text { phism }\end{array}$ \\
\hline$T_{1}$ & 5 & 0 & - & 6 & 0 & - \\
\hline$T_{2}$ & 4 & 0 & - & 6 & 0 & - \\
\hline$T_{3}$ & 8 & 0 & - & 11 & 0 & - \\
\hline$\overline{T_{4}}$ & 6 & 0 & - & 5 & 0 & - \\
\hline$T_{5}$ & 4 & 0 & - & 2 & 0 & - \\
\hline$T_{6}$ & 6 & 0 & - & 5 & 0 & - \\
\hline$T_{7}$ & 6 & 0 & - & 6 & 0 & - \\
\hline$T_{8}$ & 4 & 0 & - & 4 & 0 & - \\
\hline$T_{9}$ & 6 & 1 & 16.6 & 6 & 1 & 16.6 \\
\hline$T_{10}$ & 3 & 0 & - & 11 & 0 & - \\
\hline$T_{11}$ & 9 & 1 & 11.1 & 6 & 1 & 16.6 \\
\hline$T_{12}$ & 4 & 1 & 25 & 6 & 1 & 16.6 \\
\hline $\mathrm{C}_{1}$ & 5 & 0 & - & 5 & 0 & - \\
\hline $\mathrm{C}_{2}$ & 7 & 0 & - & 3 & 0 & - \\
\hline \multicolumn{2}{|c|}{ Total - 77} & 3 & \multicolumn{2}{|c|}{ Total - 82} & 3 & \\
\hline
\end{tabular}

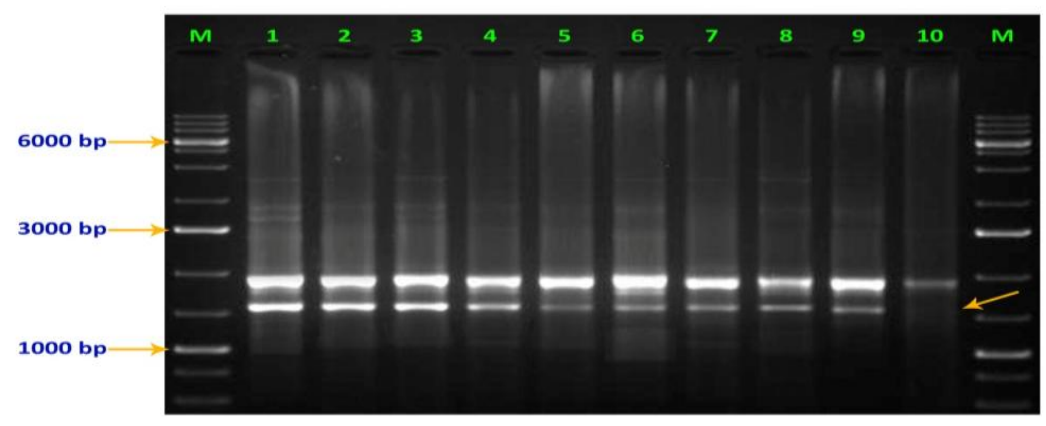

Plate No. 8 RAPD gel profile of plants derived from $T_{9}$ (EMS $1.0 \mu M$ in $\left.2008 T 42\right)$ treatment using OPA 1 primer

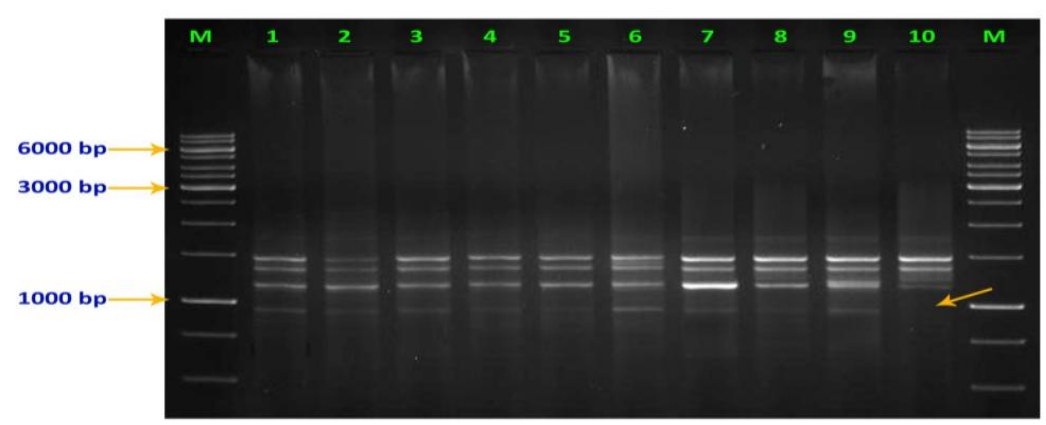

Plate No. 9 RAPD gel profile of plants derived from $T_{9}$ (EMS $1.0 \mu M$ in 2008T42) treatment using OPB 11 primer

M - 1 kb ladder

$1,2,3,4,5,6,7,8,9,10$ are plants derived from

T9 (EMS $1.0 \mu M$ in $2008 T 42)$ treatment 


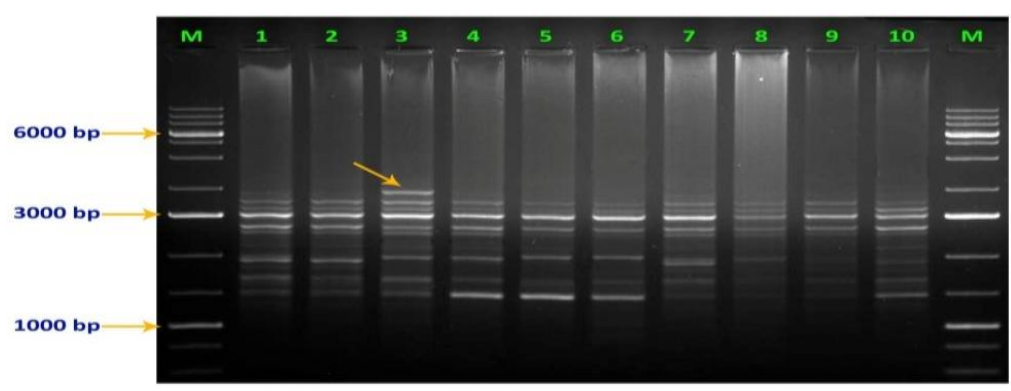

Plate No. 10 RAPD gel profile of plants derived from $T_{11}$ (EMS $0.8 \mu M$ in 2009T5) treatment using OPA 1 primer

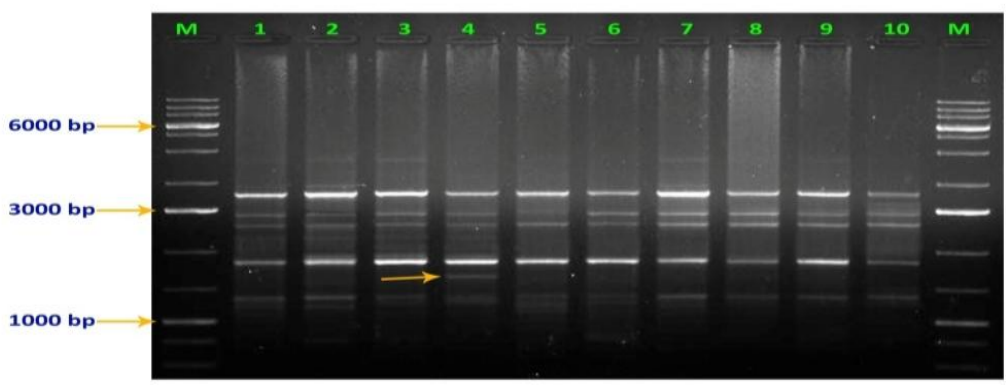

Plate No. 11 RAPD gel profile of plants derived from $T_{11}$ (EMS $0.8 \mu M$ in 200955$)$ treatment using OPB 11 primer

M - 1 kb ladder

$1,2,3,4,5,6,7,8,9,10$ are plants derived from

$T_{11}$ (EMS 0.8 $\mu M$ in 2009T5) treatment

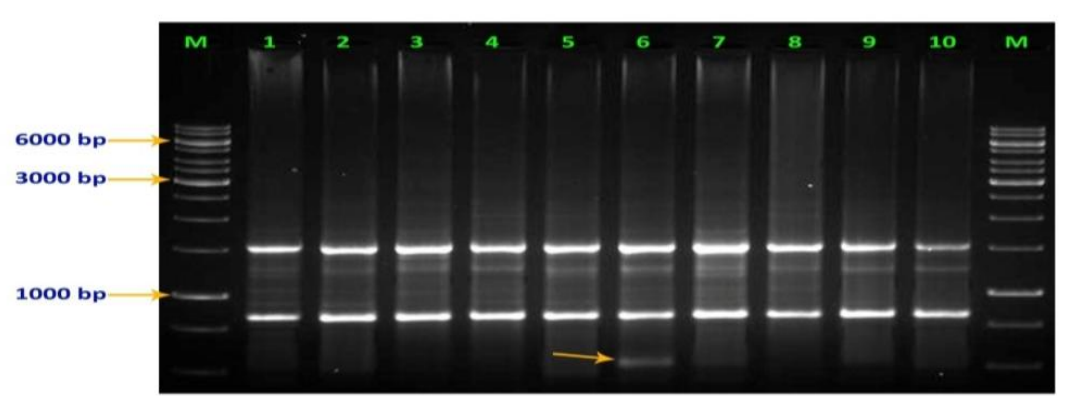

Plate No. 12 RAPD gel profile of plants derived from $T_{12}$ (EMS $1.0 \mu M$ in 2009T5) treatment using OPA 1 primer

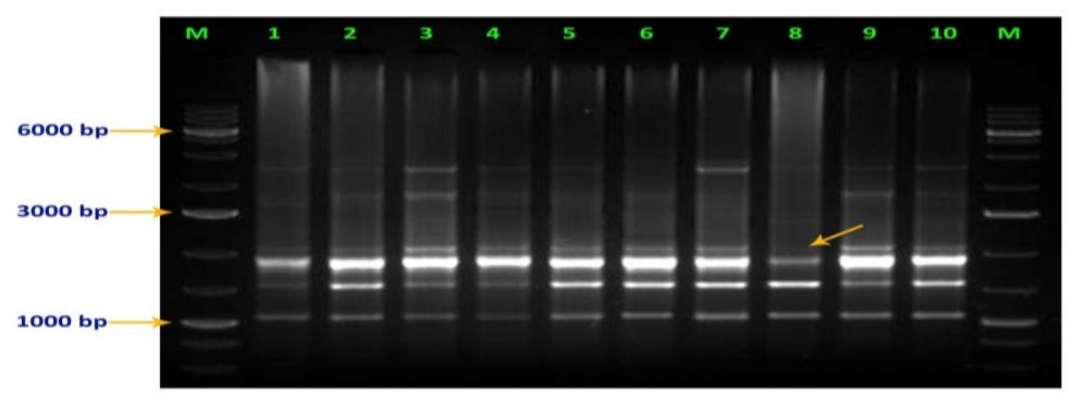

Plate No. 13 RAPD gel profile of plants derived from $T_{12}$ (EMS $1.0 \mu M$ in $\left.2009 T 5\right)$ treatment using OPB 11 primer

M - 1 kb ladder

$1,2,3,4,5,6,7,8,9,10$ are plants derived from

$T_{12}$ (EMS 1.0 $\mu M$ in 2009T5) treatment 
Many workers widely used these techniques to detect and characterize somaclonal variation at the DNA level (Ford-Lloyd et al., 1992; Cloutier and Landry, 1994; Barrett et $a l ., 1997)$. It was opined that among available techniques, RAPD was the most useful (Rani et al., 1995; Taylor et al., 1995; Shoyama et al., 1997; Todoroviska et al., 1997 and Rout et al., 1998). Changes in the RAPD pattern may result from the loss/gain of a primer annealing, caused by point mutations or by the insertion or deletion of sequences or transposition elements (Peschke et al., 1991). It was suggested that RAPD bands possibly represent mainly repetitive DNA (Grattapaglia and Sederoff, 1994). Polymorphism in repetitive DNA sequences has frequently been observed during plant propagation by tissue culture (Smulders et al., 1995) and undergoes more alterations than the coding sequences. In vitro stress may provoke changes at preferential sites, such as repetitive DNA, thereby activating transposable elements.

The two specific primers, OPA-1 and OPB 11 have shown that there existed a potential of using RAPD-PCR for detecting polymorphism in mutagenic treated cultures of 2008T42 and 2009T5 sugarcane clones. The observation of polymorphism between developed somaclones supports the conclusion that these plantlets regenerated by the method followed in the study were not likely to be genetically true to their source parents.

It can be suggested that the induction of variability using young leaf rolls as discussed in the present study could be useful in developing red rot and smut resistant somaclones from 2008T42 and 2009T5, respectively. Field evaluation and screening of somaclones for resistance to red rot and smut have to carried out in order to ascertain the usefulness of the study.

\section{References}

Barrett, C., Lefort, F and Douglas, G.C. 1997. Genetic characterization of oak seedlings, epicormic, crown and micropropagated shoots from mature trees by RAPD and microsatellite PCR. Sci. Hortic. 70: 319-330.

Cloutier, S and Landry, B.S. 1994. Molecular markers applied to plant tissue culture. In Vitro Cell. Develop. Biol. 30: 32-39.

Ford-Lloyd, B.V., Sabir, A., Newbury, H.J., Todd, C and Catty, J. 1992. Determination of genetic stability using isozymes and RFLPs in beet plants regenerated in vitro. Theor. Appl. Genet. 84: 113-117.

Grattapaglia, D and Sederoff, R. 1994. Genetic linkage maps of Eucalyptus grandis and Eucalyptus urophylla using a pseudo-testcross: mapping strategy and RAPD markers. Genetics. 137: 1121-1137.

Lakshmanan, P., Geijskes, R.J., Wang, L., Elliott, A., Grof, C.P.L., Berding, $\mathrm{N}$ and Smith, G.R. 2006. Development and hormonal regulation of direct shoot organogenesis and somatic embryogenesis in sugarcane (Saccharum spp. Interspecific hybrids) leaf culture. Plant Cell Rep. 25: 1007- 1015.

Lal, M., Singh, R.K., Srivastava, S., Singh, N., Singh, S.P and Sharma, M.L. 2008. RAPD marker based analysis of micropropogated plantlets of sugarcane for early evaluation of genetic fidelity. Sugar Tech. 10(1): 99-103.

Peschke, V.M., Phillips, R.L and Gengenbach, B.G. 1991. Genetic and molecular analysis of tissue-culturederived Ac elements. Theor. Appl. Genet. 82: 121-129.

Rani, V., Parida, A and Raina, S.N. 1995. Random amplified polymorphic DNA (RAPD) markers for genetic analysis in 
micropropagated plants of Populus deltoides Marsh. Plant Cell Rep. 14: 459-462.

Rout, G.R., Das, P., Goel, S and Raina, S.N. 1998. Determination of genetic stability of micropropagated plants of ginger using random amplified polymorphic DNA (RAPD) markers. Botan. Bull. Acad. Sin. 39: 23-27.

Shahid, M.T.H., Khan, F.A., Saeed, A., Aslam, $\mathrm{M}$ and Rasul, F. 2012. Development of somaclones in sugarcane genotype BF-162 and assessment of variability by random amplified polymorphic DNA (RAPD) and simple sequence repeats (SSR) markers in selected red rot resistant somaclones. African Journal of Biotechnology. 11(15): 3502-3513.

Shoyama, Y., Zhu, X.X., Nakai, R., Shiraishi, $S$ and Kohda, H. 1997. Micropropagation of Panax notoginseng by somatic embryogenesis and RAPD analysis of regenerated plantlets. Plant Cell Rep. 16: 450-453.

Smulders, M.J.M., Rus-Kortekass, $\mathrm{W}$ and Vosman, B. 1995. Tissue cultureinduced DNA methylation polymorphisms in repetitive DNA of tomato calli and regenerated plants. Theor. Appl. Genet. 91: 1257-1264.

Sobhakumari, V.P. 2012. Assessment of somaclonal variation in sugarcane. African Journal of Biotechnology. 11(87): 15303-15309.

Taylor, P.W.J., Geijskes, J.R., Ko, H.L., Fraser, T.A., Henry, R.J and Birch, R.G. 1995. Sensitivity of random amplified polymorphic DNA analysis to detect genetic change in sugarcane during tissue culture. Theor. Appl. Genet. 90: 1169-1173.

Todoroviska, E., Trifonova, A., Petrova, M., Vitonova, Z and Marinova, E. 1997. Agronomic performance and molecular assessment of tissue culture derived barley lines. Plant Breed. 166: 511-517.

Viera, 2002. Genetic stability of sugarcane plants derived from meristem culture. Genetic and Molecular Biology. 235(1): 91- 96.

Yadav, P., Suprasanna, P., Gopalrao, K and Anant, B. 2006. Molecular profiling using RAPD technique of salt and drought tolerant regenerants of sugarcane. Sugar Tech. 8:63-68.

\section{How to cite this article:}

Mallikarjuna S. J., M. Hemanth Kumar, D. Mohan Reddy, P. Sudhakar and Hemalatha T. 2018. Assessment of Genetic Polymorphism in Sugarcane Somaclones by Using Random Amplified Polymorphic DNA. Int.J.Curr.Microbiol.App.Sci. 7(06): 1412-1419. doi: https://doi.org/10.20546/ijcmas.2018.706.168 